\title{
Jugun Ianfu dan Hegemoni Jepang di Indonesia: Sejarah Perbudakan Seks dalam Narasi Sastra
}

Laila Wargiati ${ }^{1}$ | Indah Nur Fadilah ${ }^{2}$ | Biancha Viska Putri Dwi Setyawati ${ }^{3}$ | Taqiyuddin Jamilus Shiyam $^{4}$ | Muhammad Khodafi ${ }^{5}$

\author{
${ }^{1}$ Program Studi Sejarah \\ Peradaban Islam \\ UIN Sunan Ampel, Surabaya \\ ${ }^{2}$ Program Studi Sejarah \\ Peradaban Islam \\ UIN Sunan Ampel, Surabaya \\ ${ }^{3}$ Program Studi Sejarah \\ Peradaban Islam \\ UIN Sunan Ampel, Surabaya \\ ${ }^{4}$ Program Studi Sejarah \\ Peradaban Islam \\ UIN Sunan Ampel, Surabaya \\ ${ }^{5}$ Program Studi Sejarah \\ Peradaban Islam \\ UIN Sunan Ampel, Surabaya \\ Correspondence: \\ Laila Wargiati \\ Program Studi Sejarah \\ Peradaban Islam \\ UIN Sunan Ampel, Surabaya \\ lailawargiati@gmail.com
}

Article History:

Received 1 December 2021

Revised 21 January 2022

Accepted 24 January 2022

\section{Abstract}

The arrival of Japan became a nightmare for most Indonesian people. The Japanese occupation was accompanied by cruelty, as seen in the jugun ianfu incident, leaving scars on victims. Three research problems will be reviewed in this paper: firstly, how the development of jugun ianfu in Indonesia and how the implementation of jugun ianfu will affect Indonesia. Also, what the historical values are in the Jugun Ianfu incident. This study places Jugun Ianfu: Jangan Panggil Aku Miyako as the object of study and describes jugun ianfu as a symbol of Japanese hegemony over Indonesian women. This study uses a descriptive-qualitative method by collecting literature and documentation data. The results of this study can be summarized into three. Firstly, the development of jugun ianfu in Indonesia is very long and sad because some victims have not received their human rights. Secondly, the implementation of jugun ianfu dramatically affects the social conditions of the community as well as physical and psychological victims. Thirdly, the tragedy of jugun ianfu contains historical values that can be used as ibrah.

Keywords: Jugun ianfu, Ian-jo, Japan, historical novels.

\section{Abstrak}

Kedatangan Jepang menjadi suatu mimpi buruk bagi sebagian besar masyarakat di Indonesia. Pendudukan Jepang disertai bukti kekejaman seperti dalam peristiwa jugun ianfu yang menorehkan bekas luka bagi korbannya. Dari persoalan tersebut terdapat tiga rumusan masalah yang akan dibahas dalam tulisan ini, bagaimana perkembangan jugun ianfu di Indonesia? Bagaimana pengaruh praktik jugun ianfu di Indonesia? Bagaimana nilai-nilai sejarah dalam peristiwa jugun ianfu? Kajian ini menempatkan Jugun Ianfu Jangan Panggil Aku Miyako sebagai objek kajian dan bertujuan memaparkan sejarah jugun ianfu sebagai simbol hegemoni Jepang atas perempuan. Metode kajian ini menggunakan deskriptifkualitatif dengan mengumpulkan data literatur dan dokumentasi. Hasil kajian menunjukkan tiga hal, yaitu: perkembangan jugun ianfu di Indonesia berlangsung tragis, praktik jugun ianfu sangat mempengaruhi kondisi fisik dan psikis korbannya, dan tragedi jugun ianfu mengandung nilai-nilai sejarah yang dapat dijadikan ibrah.

Kata Kunci: Jugun ianfu, Ian-jo, Jepang, novel sejarah 


\section{Pendahuluan}

Hingga kini kasus kekerasan terhadap perempuan masih marak di Indonesia. Dari sudut pandang sejarah akar kekerasan berbasis gender telah berlangsung sejak lama, bahkan sebelum kemerdekaan Indonesia. Pendudukan Jepang yang singkat (1942-1945) menjadi satu periode kelam dalam tindak kekerasan yang perempuan sebagai korban. Untuk menyokong kampanye fasisme di Asia, Dai Nippon mengeksploitasi perempuanperempuan sebagai jugun ianfu. Jugun ianfu atau perempuan penghibur dieksploitasi untuk memberikan kesenangan banal bagi bala tentara Jepang (Elmira, 2020; Listiyanti, 2008).

Sebelum praktik jugun ianfu dilakukan, Jepang telah menyebarkan nilai-nilai hakko-ichi-u dan membaurkan ideologi tersebut dalam ranah sosial masyarakat Indonesia (Nurohmat, 2021; Savitri, 2010). Tindakan ini ditengarai sebagai siasat Jepang untuk menghegemoni masyarakat, terutama perempuan. Para perempuan dalam hal ini beranggapan dirinya diberi kesempatan ikut andil dalam perang melawan orientalisme Barat. Jamak tidak disadari jika yang dimaksud sebagai "peran" mengarah ke sumbangan atau bantuan menggunakan "tubuh". Para perempuan tersebut alpa jika mereka dikelabui, seolah-olah memiliki pilihan namun ternyata sebaliknya (Savitri, 2010).

Setelah Perang Dunia II, Jepang mulai mendirikan Ian-jo, sejenis kamp konsentrasi bagi prakrik prostitusi yang khususskan untuk tentara dan sipil Jepang. Sistem yang digunakan untuk merekrut perempuan (bahkan mereka yang masih di bawah umur) dilakukan dengan menghasut, mengintimidasi, bahkan menculik. Dalam praktiknyajugun ianfu tidak hanya menyasar perempuan pribumi, perempuan Eropa atau keturunan yang kala itu masih tersisa di Indonesia turut menjadi korban (Kemala, et al., 2020).

Menjadi jugun ianfu adalah bentuk dari nilai- nilai perempuan (hakko-ichi-u) versi militer Jepang (Savitri, 2010). Praktik perbudakan seksual berdampak besar bagi mantan jugun ianfu. Mereka tidak pernah mendapatkan hak-hak kemanusiaan, sebaliknya mereka kerapkali dicemooh setelah latar belakang mereka terungkap. Mardiyem dari Yogyakarta, misalnya, dikucilkan masyarakat setelah diketahui dirinya seorang mantan jugun ianfu. Dia mangadu dan menuntut hak-haknya sebagai korban perang (Mumpuni, 2018; Nurpratiwi, 2015). Selain Mardiyem terdapat beberapa nama seperti Sarmini, Sukarni, Lasmirah dan Lasiyem yang mengungkap kekejaman tentara Jepang terhadap jugun ianfu (Febriyanto, 2012; Kemala et al., 2020; Poesponegoro, et al., 2008).

Jamak pemberitaan, laporan, serta dokumen kajian ilmiah dilakukan untuk mengungkapkan sejarah kelam yang menimpa perempuan selama pendudukan Jepang di Indonesia. Sudut pandang korban memberikan nilai sosiologis-historis tersendiri. Hingga kini telah banyak dokumen yang dihasilkan dan dipublikasikan, termasuk karya sastra.

Novel tentang jugun ianfu mengisahkan pengalaman tragis perempuan sebagai korban tidak langsung dari Perang Pasifik. Fiksi jugun ianfu selalu erat dengan bobot historisnya. Oleh sebab itu, keberadaan novel harus ditempatkan sebagai produk kebudayaan (sejenis memori kolektif) suatu zaman yang khas. Meneladani pandangan mendiang Kuntowijoyo (2006), karya sastra yang sengaja mengkreasi peristiwa sejarah (historical truth) sebagai bahan pengkaryaan harus dipahami tidak menempatkan elemen historis sebatas ornamental. Bahan sejarah merupakan bagian integral dalam narasi pengkaryaan. Sastra dan sejarah memiliki acuan yang sama, realitas (Kuntowijoyo, 2004). Maksudnya, peristiwa masa silam dalam karya sastra senantiasa ikut beroperasi secara apriori dalam membangun struktur cerita fiksi 
(Atikurrahman et al., 2021).

Novel yang mengandung anasir-anasir sejarah kerapkali mengisahkan peristiwa lampau melalui sudut pandang pertama dalam usaha mengintegrasikan patos pembaca terkait nilainilai historis yang melatarinya. Pada beberapa bagian peristiwa dikreasi secara kreatif sebagai wujud estetika sastra yang berpangkal pada imajinasi pengarang. Tulisan ini berorientasi untuk memahami peristiwa tragis jugun ianfu di Indonesia selama kampanye Asia Timur Raya (1942-1945) dengan cara berbeda, yakni melihat dari sudut pandang sastra.

Kajian ini menempatkan Jugun Ianfu: Jangan Panggil Aku Miyako, novel sejarah gubahan Enang Rokajat Asura sebagai objek kajian. Untuk memahami nilai historis jugun ianfu, tulisan ini menempatkan peristiwa kekerasan gender menjelang kemerdekaan Indonesia sebagai pokok bahasan tulisan. Menyigi permasalahan yang dijabarkan di atas, peneliti berfokus pada elemen historis novel. Dengan memanfaatkan perspektif historis, pembacaan terhadap karya sastra (novel) sejarah dilakukan untuk mengetahui dan memahami sejarah perkembangan jugun ianfu di Indonesia, pengaruh kebijakan jugun ianfu selama perang, serta nilai-nilai sejarah dalam novel yang menempatkan tragedi jugun ianfu sebagai modus operandi pengkaryaan sastra.

Metode yang diterapkan dalam kajian ini deskriptif-kualitatif. Penelitian ini menekankan perspektif historis terkait perempuan dalam perbudakan seksual yang dilakukan militer Jepang selama menduduki Indonesia. Kajian ini mengandaikan pendekatan sejarah memiliki basis relevansi dengan objek material penelitian serta latar penelitian sehingga dapat mengkonklusikan perkembangan jugun ianfu serta pengaruhnya di Indonesia. Pendekatan sejarah bertujuan mempertajam deskripsi atas sumber-sumber maupun informasi masa lampau yang disusun secara kronologis (Haryanto, 2017). Kajian ini juga menggunakan perspektif sosiologis yang menekankan pada aspek sosial serta pandangan penulis untuk mengetahui nilai-nilai sejarah yang terjelma dalam novel.

\section{Hasil dan Pembahasan:}

\section{Perkembangan Jugun Ianfu di Indonesia}

Terdapat upaya-upaya hegemonik yang dilakukan militer Jepang selama periode singkat (1942-1945) pendudukannya di Indonesia (Jayanti, et al., 2019). Pembentukan lembaga-lembaga di luar dinas kemiliteran, seperti kelembagaan dan organisasi sosial, budaya, dan agama di masa awal kedatangan Jepang menjadi bukti historis yang tidak dapat diabaikan (Poesponegoro et al., 2008). Dalam kronik jugun ianfu, kebijakan hakko-ichi-u tentunya membuka jalan bagi militer Jepang pada masa berikutnya untuk melibatkan perempuan dalam kampanye Perang Asia Timur Raya yang mereka canangkan (Savitri, 2010).

Dalam kronik sejarah, jugun ianfu dianggap peristiwa kelam yang menimpa perempuan sebagai korban kejahatan perang. Perempuan dalam konteks itu dieksploitasi secara seksual sehingga peristiwa tersebut lebih dipahami sebagai momok yang cenderung ditutp-tutupi. Bahkan pemerintah Indonesia menganggap jugun ianfu sebagai peristiwa yang sepatutnya dihapus dalam memori historis karena dianggap sebagai aib negara (Nurpratiwi \& Putranto, 2017).

Praktik jugun ianfu dianggap memiliki dampak laten tidak hanya bagi korbannya. Pasalnya perempuan ditempatkan sebagai penghibur dan diperlakukan dalam posisi yang tidak manusiawi. Sebagai "pendukung perang", perempuan sengaja diekspolitasi sebagai budak pelampiasan seksual tentara Jepang. Dengan kata lain, jugun ianfu merupakan penopang militer Jepang dalam 
kampanye perang Asia Timur Raya. Tak sedikit perempuan yang terjerumus dalam perbudakan seks selama kampanye Perang Dunia II. Faktanya, praktik jugun ianfu ternyata tidak hanya terjadi di Indonesia. Militer Jepang melakukan hal serupa di Thailand, Filipina, Myanmar, Vietnam, Korea, Tiongkok, Malaya (Malaysia dan Singapura), India, Belanda, Eurasia, serta kepulauan Pasifik (Listiyanti, 2008).

Selama pendudukan militer Jepang, seorang jugun ianfu direkrut dari desa-desa dengan cara dipaksa dan intimidasi kekerasan, tipu muslihat, dan ancaman. Para perempuan yang menjadi jugun ianfu kebanyakan mereka yang berpendidikan rendah, tidak berpendidikan, dan buta huruf. Selain kebodohan, mereka juga terjebak dalam kesulitan ekonomi. Kebodohan dan kemiskinan membuat mereka percaya pada tawaran kerja yang cukup menjanjikan tanpa membutuhkan keahlian khusus (Poesponegoro et al., 2008).

Mulanya, praktik jugun ianfu diterapkan militer Jepang ketika melakukan ekspansi ke China sekitar 1937. Kala itu terjadi peristiwa Perkosaan Nanking dan Pembunuhan Nanjing (Komnasham, 2013). Karena maraknya tindak pemerkosaan massal yang dilakukan oleh tantara Jepang kepada perempuan China setempat banyak serdadu Jepang mengalami penyakit kelamin yang menular. Oleh sebab itu militer Jepang kemudian membuat semacam kamp khusus, ian-jo, yang steril sebagai asrama untuk menampung jugun ianfu di wilayah komando militer negara jajahan (Kemala et al., 2020; Kristi, 2016; Rahma, et al., 2020).

Pada Desember 1941 Jepang melakukan serangan mendadak ke pangkalan Angkatan Laut Amerika Serikat di Pearl Harbour. Peristiwa itu menandai dimulai Perang Pasifik yang melibatkan Amerika Serikat dan Jepang (Poesponegoro et al., 2008). Pasca penyerangan Pearl Harbour, Amerika Serikat berupaya melakukan balasan yang puncaknya terjadi pada 1945 dalam tragedi pemboman kota industri Jepang, Hiroshima dan Nagasaki (Bey, 2015; Tomonaga, 2019). Bersama Belanda, Inggris, dan Australia, Amerika Serikat membentuk sekutu (Poesponegoro et al., 2008). Jepang tidak tinggal diam dan melakukan ekspansi besar-besaran dan menduduki koloni sekutu. Di Indonesia sebagai koloni Belanda, Jepang memulai ekspansi dengan menduduki Tarakan pada Januari 1942. Keberadaan Indonesia bagi Jepang sendiri esensial. Karena wilayah ini menyediakan sumber daya alam (utamanya minyak bumi dan karet) yang dapat mendukung industrial Jepang sebagai kampanye perang Jepang (Cahyani, 2019; Hafidz, 2018).

Tidak dapat pengimbangi kekuatan militer Jepang, akhirnya pada Maret 1942 Belanda berhasil dikangkangi sehingga wilayah koloninya diwarisi militer Jepang. Kemudian Jepang mendeklarasikan prinsip yang dapat menguntungkan militernya, yakni mengusahakan dukungan rakyat Indonesia demi memenangkan perang yang mereka sebut upaya melawan imprealisme Barat (Listiyanti, 2008).

Perpindahan kekuasan dari Belanda ke Jepang berimbas pada situasi ekonomi di Indonesia. Situasi depresi tersebut dimanfaatkan Jepang untuk memperoleh simpati sehingga mendukung kampanye perang mereka. Dengan menjanjikan perbaikan pendidikan serta kemerdekaan Indonesia tidak sedikit dari orang Indonesia yang menjadi simpatisan. Seperti ditulis Pramoedya (2007) dalam Perawan Remaja dalam Cengkraman Militer, Jepang berjanji akan mendirikan lembaga pendidikan bagi generasi muda Indonesia untuk mempersiapkan sebuah bangsa mandiri dan merdeka kelak di kemudian hari. Dari sini awal mula keterlibatan masyarakat Indonesia dalam kampanye Dai Nippon, termasuk perempuan untuk kepentingankepentingan formal seperti dalam Fujinkai, serta kepentingan informal seperti dalam jugun ianfu. 
Berbeda dengan Romusha yang dilakukan terbuka, perekrutan perempuan sebagai jugun ianfu dilakukan secara tertutup. Sistem perekrutannya tidak menggunakan pengumuman resmi. Pemerintah militer Jepang menggunakan bantuan pejabat daerah seperti lurah, camat, dan melalui tonarigumi (Hindra, 2006; Poesponegoro et al., 2008). Di kemudian hari ketika persoalan jugun ianfu hendak diangkat ke tengah publik dan/atau dilakukan pengusutan keberadaan bukti-bukti otientik menjadi salah satu tantangan tersendiri.

Di setiap wilayah komando militer penguasa militer Jepang mendirikan tempat-tempat huni jugun ianfu. Tujuannya mencegah terjadinya pemerkosaan oleh tentara Jepang terhadap penduduk lokal, menjaga moral tentara, serta mencegah penyakit kelamin yang dapat melemahkan kekuatan militer Jepang (Poesponegoro et al., 2008). Perempuan yang dijadikan jugun ianfu dimasukkan ke rumah-rumah bordil yang disebut Ian-jo, seperti bekas asrama peninggalan Belanda, markas militer jepang, dan rumah-rumah penduduk yang sengaja dikosongkan. Tempat-tempat tersebut dijaga ketat oleh militer Jepang. Setiap perempuan di Ian-jo mendapatkan kamar bernomor. Nama jugun ianfu yang tak lain adalah perempuan lokal diganti dengan nama Jepang ditulis pada pintu kamar (Hindra, 2006). Seperti Mardiyem yang diganti menjadi Momoye, Waginem menjadi Sakura, Suharti menjadi Masako, Nur menjadi Noburo, dan Jatiyem menjadi Haruye (Hartono \& Juliantoro, 1997; Hindra \& Kimura, 2007; Savitri, 2010).

Selama di Ian-jo perempuan jugun ianfu mengalami pemerkosaan. Mereka disiksa sehingga mengakibatkan cacat fisik dan gangguan psikis (trauma) akibat perbudakan seksual (Hindra \& Kimura, 2007). Siksaan berupa tamparan, pukulan, dan tendangan dilakukan tentara Jepang, terlebih ketika mabuk. Para perempuan itu hanya pasrah menjalani penderitaan karena tidak punya pilihan lain. Kesempatan untuk melarikan diri bisa disebut mustahil karena perjalanan pulang yang jauh sedangkan mereka buta pengetahuan geografi, di samping tidak punya uang untuk berpergian (Poesponegoro et al., 2008).

\section{Pengaruh Pelaksanaan Jugun Ianfu di Indonesia}

Meskipun di Ian-jo berlaku sistem pembayaran karcis namun jugun ianfu tidak pernah menerima uang sepeser pun dari karcis yang mereka terima dari tamu. Setiap pengunjung diharuskan mengantre demi mendapatkan karcis (serta kondom). Karcis diserahkan dan dikumpulkan jugun ianfu sehingga kelak dapat ditukar dengan uang tatkala berhenti bekerja dari Ian-jo (Hindra, 2006). Besaran nominal pembayaran tidak sama. Kalangan militer yang berkunjung siang hari dikenakan biaya 2,5 rupiah sedangkan pihak sipil sejumlah 3,5 rupiah. Waktunya dimulai sore, pukul 17.00 hingga pukul 24.00. Bagi pengunjung yang menginap hingga pagi harus merogoh kantong hingga 12,5 rupiah (Poesponegoro et al., 2008).

Pada kenyataannya seorang jugun ianfu hanya menerima karcis tanpa pernah menerima sepeser pun uang. Meskipun pengelola Ian-jo mengatakan jika karcis yang terkumpul dapat ditukar dengan uang setelah tidak bekerja di kamp perbudakan seks tersebut. Dalam perkembangannya, janji itu tidak pernah ditepati. Akhirnya penghuni Ian-jo hanya bisa pasarah tidak memedulikan uang karcis yang harusnya mereka terima. Mardiyem, seorang bekas jugun ianfu, menunjukkan koleksi karcis miliknya lebih satu keranjang besar. Dia dan kawankawannya di Ian-Jo Telawang, Kalimantan Selatan tidak pernah mendapatkan uang dari karcis koleksi mereka (Hartono \& Juliantoro, 1997).

Ketika tiba di Ian-jo Telawang, Mardiyem diberi nama Jepang Momoye. Dia salah satu di antara 24 perempuan gelombang pertama yang dijebak menjadi jugun ianfu. Semula mereka hendak mencari 
kerja guna mengubah nasib, namun akhirnya dihasut dan dipaksa menjadi budak seks. Pada 1943 datang 35 perempuan lain sebagai penghuni baru Ian-jo Telawang. Kedatangan jugun ianfu gelombang kedua tersebut berimbas pada jatah makan penghuni kamp perbudakan seks. Jumlah penghuni yang bertambah berakibat pada penurunan kualitas makanan. Jatah daging yang biasa diterima mulai berkurang bahkan tidak ada sama sekali. Namun mereka dipaksa melayani tamu dari pukul 12.00 hingga keesokan harinya. Lalu, kedatangan sembilan orang jugun ianfu lain pada 1944 menambah rumit kondisi Ianjo Telawang. Mereka hanya dijatah makan sekali sehari. Dengan kondisi demikian, mereka tetap dipaksa melayani kebutuhan seks sampai akhirnya Jepang kalah pada 1945 (Hindra \& Kimura, 2007).

Selama berada di Ian-jo mereka mengalami perbudakan seksual. Mardiyem, misalnya, baru genap berusia 13 tahun dan belum haid pada hari pertama menjadi jugun ianfu. Pada hari nahas itu dia dipaksa melayani enam orang laki-laki sekaligus hingga mengalami pendarahan. Ketika berumur 15 tahun Mardiyem hamil dan dipaksa menggugurkan kandungannya yang berusia lima bulan. Perutnya ditekan secara paksa oleh dokter tanpa pembiusan. Kisah tragis lain yang tak kalah pilu dialami Giyah. Setelah tinggal di Ian-jo Telawang badan Giyah menjadi kurus dan akhirnya meninggal. Mayat Giyah ditumpuk bersama korban romusha dan dibiarkan begitu saja hingga membusuk di Pasar Lama (Poesponegoro et al., 2008).

Sumirah yang menolak permintaan tentara Jepang mendapatkan siksaan fisik berupa pukulan dan tendangan. Akhirnya Sumirah hanya pasrah menerima perlakuan tak manusiawi Jepang terhadapnya. Seperti Mardiyem, Kastimah dipaksa menjadi budak seks sejak umur 13 tahun (Cahya, 2015). Sedangkan di Jawa Barat korban jugun ianfu tersebar di Bogor, Sukabumi, Cimahi, serta Sumedang. Awalnya mereka dijanjikan pekerjaan namun ternyata mereka malah dijebaksebagai budak seks militer Jepang. Mereka mengalami kekerasan, penyiksaan dan perkosaan yang berdampak traumatis bagi korbannya yang kebanyakan remaja yang tersebar di Jawa Barat (Rahma, et al., 2020).

Penyiksaan memang kerapkali diterima oleh jugun ianfu yang menolak melayani hasrat libidinal pihak militer Jepang. Sehingga seorang jugun ianfu bisa mengalami cacat fisik dan gangguan psikis terhadap korbannya. Kerena tidak punya pilihan, para jugun ianfu hanya pasrah menjalani penderitaan selama tinggal di kamp Ian-jo Telawang (Poesponegoro et al., 2008).

Perempuan yang dipaksa menjadi jugun ianfu menyisakan penderitaan lahir-batin. Hal ini merupakan salah satu bukti kekejaman militer Jepang dalam mengeksploitasi perempuan demi menyokong kampanye Asia Timur Raya. Dalam Perawan Remaja dalam Cengkeraman Militer, Pramoedya (2007) secara apik menggambarkan kisah perempuan-perempuan muda yang menjadi korban kekejaman militer Jepang selama Perang Dunia II. Pasca kekalahan Jepang dari sekutu, para penghuni Ian-jo ditinggalkan begitu saja tanpa kejelasan nasib. Genaplah penderitaan mereka sebagai korban kekerasan perang.

Selain stigma negatif banyak perempuan korban jugun ianfu memilih bungkam karena takut dikucilkan masyarakat. Hanya sebagian kecil dari mereka yang tegar menuntut keadilan atas perlakukan militer Jepang. Sebelumnya, telah banyak tuntutan dari korban eksplotasi perempuan Korea, Filipina, Taiwan dan China. Keadilan yang dimaksud berupa permintaan maaf pemerintah Jepang secara langsung kepada korban perbudakan seksual oleh militer Jepang serta kompensasi sesuai dengan upah yang harusnya mereka terima selama diperalat sebagai budak seks tantara Jepang. Minimal, pemerintah Jepang melakukan klarifikasi dan penjelasan sehingga pandangan negatif 
terhadap mereka sebagai korban jugun ianfu tidak lagi terjadi. Akan tetapi pemerintah Jepang tidak pernah menanggapi tuntutan tersebut. Mereka beralasan tidak ada bukti otientik sehingga polemik jugun ianfu sekadar menimbulkan pro dan kontra, bahkan di Jepang sendiri. Pemerintah Jepang menyatakan praktik jugun ianfu tidak pernah ada. Perempuan-perempuan tersebut tak lebih disebut pelacur (Cahya, 2015).

Di Indonesia perjuangan menuntut keadilan bagi korban kekerasan perang bermotif perbudakan seks diinisiasi oleh advokasi dari Jepang. Mereka mendatangi Ikatan Advokat Indonesia (Ikadin) guna membantu mengumpulkan data korban jugun ianfu. Hasil persidangan memvonis Kaisar Hirohito bersalah yang dibuktikan dengan ditemukannya alat-alat keperluan seks seperti jarum suntik, pengaman (kondom), obat-obatan, dan kontrasepsi di Ian-jo Telawang. Tujuan persidangan bukan bermotif balas dendam, semata-mata korban jugun ianfu berhak mendapatkan keadilan dan pengakuan sebagai korban militer Jepang. Dengan kata lain, praktik keji perbudakan seksual memang terjadi selama militer Jepang menduduki Indonesia (Hindra \& Kimura, 2007).

Kasus perkara perbudakan seks selama pendudukan Jepang (1942-1945) ditangani oleh LBH Yogyakarta yang dibantu CFR (Citizens Fund For Redress World II Victimis in Asia And The Pasific). Hasilnya didapatkan sebuah kesepakatan, yakni dana kesehatan bagi korban jugun ianfu sebesar 50.000 yen setiap bulan. Selain itu, LBH Yogyakarta berharap pemerintah Indonesia tidak lepas tangan atas nasib korban jugun ianfu yang masih tersisa.

Pembelaan yang dilakukan LBH Yogyakarta atas nasib korban jugun ianfu terhadap pemerintah Jepang didukung oleh LSM lainnya. Sementara pemerintah Indonesia tidak terlalu menanggapi dan cenderung menyerahkan kasus tersebut ke LBH Yogyakarta. Sikap tersebut disebabkan pada
1958 pemerintah Indonesia telah menandatangani sebuah perjanjian dengan pemerintah Jepang terkait pendudukan pada 1942-1945 di mana pihak pemerintah Jepang menawarkan bantuan ekonomi. Meskipun perjanjian itu tidak berkaitan dengan jugun ianfu, pemerintah Indonesia tidak berniat menindaklanjuti kasus tragis tersebut (Cahya, 2015).

Pada akhirnya pemerintah Jepang mengakui praktikjugun ianfu selama pendudukan di Indonesia. Pemerintah Jepang tetap tidak melakukan permintaan maaf secara pribadi terhadap mantan jugun ianfu. Pemerintah Jepang berdalih jika praktik perbudakan seks dilakukan pihak swasta atau perorangan. Pihak Jepang memberikan dana santunan sejumlah 380 juta yen yang diangsur selama 10 tahun. Pada 25 Maret 1997 pemerintah Indonesia dan Jepang melakukan Memorandum of Understanding (MoU) terkait pemberian dana kompensasi korban jugun ianfu (Hindra \& Kimura, 2007).

\section{Nilai-nilai Sejarah dalam Novel Historis Jugun} Ianfu

Praktik jugun ianfu dilakukan militer Jepang secara masif terhadap negara-negara yang mereka duduki. Pihak Jepang berusaha mengaburkan polemik seputar jugun ianfu sehingga tak sedikit korban kekerasan perang tersebut merasa hak asasi mereka sengaja dihilangkan.

Dalam konteks Indonesia, praktik jugun ianfu dapat disebut ikut andil dalam membentuk desain sejarah sosial Indonesia. Suasana tersebut dapat ditangkap pada bagian awal novel Enang Rokajat Asura,Jugun Ianfu:Jangan Panggil Aku Miyako. Dalam narasi novel disebutkan, bahwa awalnya Jepang datang ke Hindia Belanda untuk berdagang dengan persetujuan pihak pemerintahan Hindia Belanda. Setelah mendapatkan jaminan dari penguasa, pihak Jepang mulai mendirikan toko kelontong di 
Surabaya. Pada 1925 perkumpulan orang Jepang mulai mendirikan sekolah pertama di Surabaya. Lantas, lima tahun berselang pihak pemerintah mulai mencium gelagat yang mencurigakan dari orang-orang Jepang di Hindia Belanda. Pemerintah Hindia Belanda menyadari jika orang-orang Jepang di Jawa tidak hanya berdagang. Mereka membawah misi penguasaan wilayah (Asura, 2015).

Singkat cerita, pada 9 Maret 1943 pihak Belanda akhirnya kalah dan menyerahkan wilayah koloninya kepada militer Jepang tanpa syarat. Setelah itu dimulailah pendudukan Jepang atas Indonesia. Dalam Jugun Ianfu: Jangan Panggil Aku Miyako Asura menjelaskan keterkaitan Perang Pasifik, Kampanye Asia Timur Raya, serta periode singkat (1942-1945) pendudukan Jepang terhadap Indonesia. Selain kebiadaban romusha, militer Jepang juga melakukan praktik penjualan perempuan, baik pribumi, keturunan Tionghoa, serta perempuan Eropa yang masih tersisa di Indonesia. Mereka dijadikan budak seks dan disebut jugun ianfu.

Dalam novel tersebut disebutkan nama-nama jugun ianfu seperti Lasmirah (diberi nama Jepang, Miyako), Mintarsih (Sakura), Rosa (Ayumi), dan masih banyak lagi perempuan lain. Para jugun ianfu tersebut berasal dari daerah di Jawa, Lasmirah disebutkan berasal dari Yogyakarta, Mintarsih berasal dari Bandung, dan sebagainya. Mereka dijemput lalu dibawa ke Surabaya sebelum akhirnya ditempatkan di sebuah kamp, Ian-jo yang berada di Telawang, Borneo, Kalimantan Selatan. Dari total 40 orang yang dibawa hanya 24 perempuan yang akhirnya dibawa ke Ian-jo Telawang. Mereka dijadikan jugun ianfu, sebagai budak seks militer dan sipil Jepang (Asura, 2015).

Pihak Belanda pernah melaporkan praktik jugun ianfu atau perempuan penghibur yang terjadi di Kalimantan Barat. Disebutkan, perempuanperempuan itu dipaksa militer Jepang menjadi budak seks. Mereka dikumpulkan menjadi satu pada sebuah komplek pelacur. Penghuni Ian-jo tersebut tidak diperbolehkan keluar tanpa izin khusus dari pengelola asrama pelacur tersebut. Sehingga dapat disebutkan, bahwa praktik jugun ianfu tersebut sangat terkendali dan dipantau oleh pemerintahan Jepang. Tak hanya di Kalimantan, para perempuan muda Jawa tersebut dibawa ke beberapa wilayah komando militer seperti Sulawesi, Kalimantan, Maluku, Pulau Buru, dan tentu saja Jawa (Firman, 2017).

Dalam Jugun Ianfu: Jangan Panggil Aku Miyako, Asura mengisahkan pengalaman getir perempuan jugun ianfu sebagai korban kekejaman militer Jepang. Novel tersebut mengandung nilai-nilai historis atau fakta sejarah Indonesia yang jarang sekali diungkap ke publik (Suryani, et al., 2019). Dalam menceritakan kondisi Indonesia di bawah pendudukan Jepang, pengarang sengaja mengambarkan keriskanan perempuan dan ketidakadilan yang mereka dapatkan melalui gambaran nasib seorang jugun ianfu.

Melalui gambaran seorang Lasmirah yang dipanggil Miyako novel tersebut berfokus pada pengalaman getir seorang jugun ianfu yang disiksa secara seksual oleh pihak militer Jepang. Pertama, seseorang jugun ianfu bukan tengah melakukan pengorbanan untuk membela negaranya, seperti halnya romusha. Kedua, pada masa itu seorang perempuan sama sekali tidak memiliki pilihan. Mereka sepenuhnya terkontrol oleh militer Jepang. Ketiga, media massa seperti Borneo Shimbun tidak pernah mengekspos berita tentang tempat prostitusi di Telawang tersebut, meskipun kantor berita tersebut tak jauh dari Ian-jo Telawang. Pendek kata, praktik jugun ianfu itu seakan-akan tidak pernah terjadi atau justru legal. Perlu diketahui, media massa di masa pendudukan Jepang berfungsi sebagai alat agitasi dan propaganda militer untuk memenangkan perang melawan sekutu. Sehingga di luar kepentingan militer, seperti perbudakan 
seks, kerja paksa, dan sebagainya tidak dianggap pentingt (Asura, 2015).

Dalam perkembangan novel diceritakan seorang anggota Pembela Tanah Air (PETA) bernama Pram. Sebagai milisi sukarelawan bikinan Jepang, Pram merasa terpanggil untuk bergabung dengan PETA supaya Belanda tidak menduduki wilayah Indonesia. Dalam perjuangannya, Pram bertemu Lasmirah dan jatuh cinta kepada perempuan muda tersebut. Dari situ, Pram berusaha untuk membebaskan para jugun ianfu (terutama Lasmirah) dari kamp Ian-jo yang sangat ketat tersebut. Pram merasa iba kepada jugun ianfu setelah mendengar cerita sebagian perempuan penghibur itu dipulangkan karena sakit parah, rahim rusak, buta, dan sebagainya. Ketika dipulangkan, mereka tidak diberi pesangaon atau uang pertukaran karcis yang dijanjikan. Kisah heroic Pram mendapatkan tantangan besar karena Yamada rupanya juga menaruh hati pada Lasmirah (Asura, 2015).

\section{Kesimpulan}

Sejarah kelam jugun ianfu berakar dari kampanye Asia Timur Raya yang dilakukan oleh militer Jepang di beberapa negara Asia. Di Indonesia praktik perbudakan seksual menampilkan kekhasannya. Sebagai penghibur, perempuan jugun ianfu menjadi tumbal perang Pasifik yang melibatkan sekutu Amerika Serikat demi persaingan industrial negaranegara yang disebut mapan tersebut. Perempuan korban jugun ianfu berasal dari berbagai wilayah di Indonesia seperti Jawa, Sulawesi, Sumatra, Kalimantan, dan Bali. Awalnya mereka berhasrat mencari penghidupan yang lebih layak dengan menerima pekerjaan yang ditawarkan pemerintah militer Jepang. Ternyata mereka ditempatkan di Ian-jo selama hampir tiga tahun (1942-1945) dan menjalani hidup sebagai jugun ianfu atau perempuang penghibur yang melayani hasrat banal militer dan sipil Jepang.

Pengaruh jugun ianfu berakibat pada kekerasan fisik dan psikis korban yang notabene adalah perempuan muda desa yang minim pendidikan. Pengunjung tetap Ian-jo, terutama tentara Jepang, tidak segan untuk menendang, menampar, dan mencederai para jugun ianfu yang menolak keinginan mereka untuk bersenang-senang. Lacur, para perempuan penghuni Ian-jo itu tidak pernah menerima sepersen pun uang meskipun mereka dieksploitasi melewati batas manusiawi. Pasca pendudukan Jepang, para korban kekerasan seksual tersebut masih mengalami perundungan dari pandangan sinis dan stigma negatif masyarakat.

Sedangkan nilai sejarah yang terkandung dalam Jugun Ianfu: Jangan Panggil Aku Miyako karya Enang Rokajat Asura memberikan penegasan tentang kronik kekerasan terhadap perempuan pada periode singkat pendudukan Jepang. Melalui kisah asmara antara Lasmirah dan Pram nuansa historis tersebut dibungkus dengan situasi Perang Pasifik (1941-1945) yang mempengerahi situasi Indonesia.

\section{Daftar Pustaka}

Asura, E. R. (2015). Jugun Ianfu: Jangan Panggil Aku Miyako. Depok: Edelweiss.

Atikurrahman, M., Ilma, A. A., Dharma, L. A., Affanda, A. R., Ajizah, I., \& Firdaus, R. (2021). Sejarah Pemberontakan dalam Tiga Bab: Modernitas, Belasting, dan Kolonialisme dalam Sitti Nurbaya. SULUK: Jurnal Bahasa, Sastra, Dan Budaya, 3(1). https://doi.org/10.15642/suluk.2021.3.1.1-22 Bey, A. (2015). Bom Atom di Atas Hiroshima) Suatu Pengalaman Nyata. Journal of the Medical Sciences (Berkala Ilmu Kedokteran), 21(03). Retrieved from https://jurnal.ugm.ac.id/bik/article/view/4604 Cahya, A. D. M. (2015). Upaya Masyarakat Indonesia dalam Memperjuangkan Keadilan Jugun Ianfu 
Tahun 1993-1997 (Universitas Jember). Retrieved from http://repository.unej.ac.id/ handle/123456789/72440

Cahyani, H. R. D. (2019). Perebutan Minyak Bumi Di TarakanPada Era Perang Dunia II dalam Dokumenter Sejarah "Minyak dan Darah Di Bumi Paguntaka” (Institut Seni Indonesia Yogyakarta). Retrieved from http://digilib.isi.ac.id/5718/3/JURNAL_2019_1410061432_HERLIANA RIGEL.pdf

Elmira, G. (2020). Jugun Ianfu: The Darkest History of Human Rights Violation. The Indonesian Journal of International Clinical Legal Education, 2(4), 481-490. https://doi.org/https://doi.org/10.15294/ ijicle.v2i4.43168

Febriyanto, I. (2012). Pandangan Masyarakat Indonesia (1991-1997) Terhadap Perjuangan "Jugun Ianfu" dalam Mencari Keadilan (Universitas Indonesia). Retrieved from https://lib.ui.ac.id/ file?file=digital/20315454-S43888-Pandangan masyarakat.pdf

Firman, T. (2017, January 15). Jugun Ianfu, Budak Wanita di Masa Penjajahan Jepang. Retrieved January 21, 2022, from Tirto.id website: https://tirto.id/jugun-ianfu-budak-wanita-di-masa-penjajahanjepang-cgZz

Hafidz, M. Y. (2018). Pendudukan Jepang di Kalimantan Timur 1942-1945 (Universitas Indonesia). Retrieved from https://lib.ui.ac.id/file?file=pdf/abstrak-127050.pdf

Hartono, A. B., \& Juliantoro, D. (1997). Derita Paksa Perempuan: Kisah Jugun Ianfu Pada Masa Pendudukan Jepang, 1942-1945. Jakarta: Sinar Harapan.

Haryanto, S. (2017). Pendekatan Historis dalam Studi Islam. Manarul Qur'an: Jurnal Ilmiah Studi Islam, 17(1), 127-135. https://doi.org/10.32699/mq.v17i1.927

Hindra, E. (2006). Jugun Ianfu, Kejahatan Perang Asia-Pasifik yang Belum Terselesaikan.

Hindra, E., \& Kimura, K. (2007). Momoye: Mereka Memanggilku. Jakarta: Esensi.

Jayanti, N. E., Effendy, C., \& Priyadi, A. T. (2019). Feminisme dalam Novel Momoye Mereka Memanggilku Karya Eka Hendra dan Koichi Kimura. Jurnal Pendidikan Dan Pembelajaran Khatulistiwa, 8(3), 1-12. Retrieved from https://jurnal.untan.ac.id/index.php/jpdpb/article/view/32564

Kemala, A., Harnowo, S., \& Utama, A. P. (2020). "Ianfu” di Indonesia dan Nihilnya Rekonsiliasi. Jurnal Damai Dan Resolusi Konflik, 6(1), 1-29. Retrieved from http://jurnalprodi.idu.ac.id/index.php/DRK/ article/view/497

Komnasham. (2013). Pengadilan Kejahatan Perang Internasional Terhadap Perempuan. Jakarta: Komnasham. Kristi, R. (2016). Perbedaan Respon Indonesia dan Korea Selatan Dalam Penyelesaian Jugun Ianfu Terhadap Jepang. Jurnal Analisis Hubungan Internasional, 5(2), 323-332. Retrieved from http://journal. unair.ac.id/JAHI@perbedaan-respon-indonesia-dan-korea-selatan-dalam-penyelesaian-jugunianfu-terhadap-jepang--article-11038-media-131-category-8.html

Kuntowijoyo. (2004). Sejarah / Sastra. Humaniora, 16(1), 17-26. https://doi.org/https://doi.org/10.22146/ jh.803

Kuntowijoyo. (2006). Budaya dan Masyarakat. Yogyakarta: Tiara Wacana.

Listiyanti, D. K. (2008). Jugun Ianfu Pada masa Pendudukan Jepang di Indonesia (1942-1945): Sebuah Analisi Perspektif Gender (Universitas Indonesia). Retrieved from https://lib.ui.ac.id/ file?file=digital/125822-RB08L199j-Jugunianfu pada-HA.pdf

Mumpuni, R. T. M. (2018). Peran Mardiyem dalam Memperjuangkan HAM Sebagai Bekas Jugun Ianfu 1993- 
1997 (Universitas Sanata Dharma). Retrieved from http://www.library.usd.ac.id/Data PDF/F. Keguruan dan Ilmu Pendidikan/Pendidikan Sejarah/121314032_full.pdf

Nurohmat, A. (2021). Motif Jepang Sebelum Menginvasi Hindia Belanda Tahun 1942-1945. Jejak: Jurnal Pendidikan Sejarah, 1(2), 52-56. Retrieved from https://online-journal.unja.ac.id/jejak/article/ view/15749

Nurpratiwi, H. (2015). Kiprah Mardiyem dalam Memperjuangkan Hak-Hak mantan Jugun Ianfu di Yogyakarta (1993-2007) (Universitas Negeri Yogyakarta). Retrieved from https://eprints.uny. ac.id/22751/1/SKRIPSI.pdf

Nurpratiwi, H., \& Putranto, A. (2017). Sejarah dan Fakta Kekinian Historiografi Perempuan (Jugun Ianfu) Masa Pendudukan Jepang di Indonesia. Retrieved from http://jurusan.iain-tulungagung.ac.id/ tadrisips/wp-content/uploads/sites/117/2019/04/SEJARAH-DAN-FAKTA-KEKINIAN.pdf

Poesponegoro, M. D., Notosusanto, N., Soejono, R. P., \& Leirisa, R. Z. (2008). Sejarah Nasional Indonesia VI: Zaman Jepang dan Zaman Republik. Jakarta: Balai Pustaka.

Rahma, A. D., Suswandari, S., \& Naredi, H. (2020). Jugun Ianfu: Kekerasan Seksual Terhadap Perempuan Pada Masa Pendudukan Jepang di Jawa Barat Tahun 1942-1945. Chronologia, 1(3), 36-49. Retrieved from https://journal.uhamka.ac.id/index.php/jhe/article/view/4731

Savitri, D. (2010). Kejahatan Perang Oleh Jepang (Studi Kasus Terhadap Jugun-Ianfu Sebagai Hegemoni Kebudayaan di Indonesia Periode 1942-1945). Jurnal Kriminologi Indonesia, 6(3), 284-295.

Suryani, L., Priyadi, T., \& Wartiningsih, A. (2019). Feminisme Dalam Novel Jugun Ianfu: Jangan Panggil Aku Miyako Karya E. Rokajat Asura. Jurnal Pendidikan Dan Pembelajaran Khatulistiwa, 8(3), 1-11. Retrieved from https://jurnal.untan.ac.id/index.php/jpdpb/article/view/32296/75676580781

Toer, P. A. (2007). Perawan Remaja dalam Cengkeraman Militer. Jakarta: Kepustakaan Populer Gramedia.

Tomonaga, M. (2019). The Atomic Bombings of Hiroshima and Nagasaki: A Summary of the Human Consequences, 1945-2018, and Lessons for Homo sapiens to End the Nuclear Weapon Age. Journal for Peace and Nuclear Disarmament, 2(2), 491-517. https://doi.org/10.1080/25751654 .2019 .1681226 